\title{
The Effects of the Carbon Source on Glutamate Dehydrogenase Activities in Aspergillus nidulans
}

\author{
By M. J. HYNES \\ Department of Genetics, La Trobe University, \\ Bundoora, Victoria 3083, Australia
}

(Received 3 August 1973)

\begin{abstract}
SUMMARY
The NADP-specific glutamate dehydrogenase (NADP-GDH) activity of Aspergillus nidulans was rapidly lost from cultures starved for a carbon source. This loss of NADP-GDH was blocked by protein synthesis inhibitors. Glutamate repressed NADP-GDH but did not cause rapid loss of activity. Since NADP$\mathrm{GDH}$ is involved in the participation of ammonium in the regulation of nitrogen metabolism, the loss of NADP-GDH activity accompanying carbon starvation may be important in the interaction between carbon and nitrogen metabolism. Increased NAD specific glutamate dehydrogenase activity (NAD-GDH) was observed when mycelium was transferred to medium lacking glucose. The increase in NAD-GDH activity was greatest when glutamate was present. Protein synthesis inhibitors did not prevent this increase in activity.

Two mutants, amdTIO2 and amdTI9, which are altered in regulation of nitrogen metabolism, are similar to the wild-type strain with regard to regulation of NADP-GDH and NAD-GDH.
\end{abstract}

\section{INTRODUCTION}

Mutants in a gene, amdT, in Aspergillus nidulans pleiotropically affect the utilization of many nitrogen sources (Hynes, I973a). The utilization of L-glutamate is affected in amdT mutants. One mutant, amd $T_{19}$, is unable to utilize glutamate as a sole nitrogen source in the presence of glucose, but grows normally on glutamate as the sole source of carbon and nitrogen. Another mutant, amdTI02, grows slightly more strongly than wild-type strains on glutamate as the sole nitrogen source in the presence of glucose and is normal on glutamate as the sole carbon and nitrogen source. This has led to a study of the effects of the carbon source on glutamate metabolism. This paper describes the effects of the carbon source on glutamate dehydrogenase activities in the wild type as well as amdT mutants. Studies on glutamate uptake will be reported elsewhere (Hynes, I973 $b$ ).

\section{METHODS}

Strains, media and genetic techniques. These have been described in previous papers (Hynes, 1970, 1972).

Growth of mycelium. Mycelium was grown as described previously (Hynes, 1972). In some experiments 20 to $30 \mathrm{ml}$ of mycelium was sampled at various times and harvested by the normal method.

Preparation of cell-free extracts. Crude cell-free extracts were made in $\mathrm{IO}^{-1} \mathrm{M}$-tris (hydroxy methyl) amino methane (tris)-hydrochloride buffer ( $\mathrm{pH} \mathrm{8.5)} \mathrm{by} \mathrm{the} \mathrm{method} \mathrm{of} \mathrm{Hynes}$ (1972). 
Enzyme assays. Nicotinamide adenine dinucleotide phosphate (NADP)-specific glutamate dehydrogenase (NADP-GDH) was assayed by following the glutamate-dependent reduction of NADP ${ }^{+}$at $340 \mathrm{~nm}$. The method of Pateman (1969) was followed except that double the concentration of glutamate was used.

Nicotinamide adenine dinucleotide (NAD)-specific glutamate dehydrogenase (NADGDH) was assayed by following the 2-oxoglutarate-dependent oxidation of reduced NAD at $340 \mathrm{~nm}$. The method was based on that of Kapoor \& Grover (1970) and H. Arst (personal communication). The reaction mixture contained: $1 \cdot 0 \mathrm{ml} \mathrm{IO}^{-1} \mathrm{M}$-tris-hydrochloride buffer (pH 8.5), $\mathrm{I} .8 \mathrm{ml}$ water, $6.6 \mathrm{mg}\left(\mathrm{NH}_{4}\right)_{2} \mathrm{SO}_{4}, 0.5 \mathrm{mg}$ reduced $\mathrm{NAD}$, and $\mathrm{O} \cdot \mathrm{I} \mathrm{ml}$ crude extract. The assay was begun by adding $0.1 \mathrm{ml}$ of 2 -oxoglutarate $(14.6 \mathrm{mg} / \mathrm{ml}$ ). The assays were carried out at 25 to $28{ }^{\circ} \mathrm{C}$ in a Beckman DB spectrophotometer. All NAD-GDH assays of mycelium were performed within $48 \mathrm{~h}$ of harvesting as there were indications that the enzyme was unstable under the conditions employed for storing harvested mycelium $\left(-\mathrm{I} 2{ }^{\circ} \mathrm{C}\right)$.

\section{RESULTS}

It has been found that the presence or absence of glucose in the growth medium has profound effects on both NADP-GDH and NAD-GDH activities.

NADP-GDH specific activity was found to be maintained in medium containing glucose. Pateman (1969) has presented evidence for repression of NADP-GDH by glutamate in Aspergillus nidulans. It was found that incubation in glucose-25 mM-glutamate medium did not lead to rapid loss of enzyme activity, but rather to an activity consistent with cessation of enzyme synthesis and dilution of preformed enzyme during subsequent growth.

NADP-GDH activity was rapidly lost in medium lacking glucose (Fig. I, Table I). This was most rapid when glutamate was present. The protein synthesis inhibitors, cycloheximide and acriflavin, prevented this rapid loss of activity, suggesting the possibility that an inactivating protein (possibly a protease) is active in the absence of glucose. J. R. Kinghorn (personal communication) has also observed this rapid loss of NADP-GDH. Preliminary results indicate that glutamine synthetase activity is rapidly lost with carbon starvation. Another enzyme of nitrogen metabolism, nitrate reductase, also rapidly decreases with carbon starvation, but this loss of activity is only slightly inhibited by cycloheximide (Hynes, I973c). In other fungi and higher eukaryote systems enzyme inactivation has been observed (Ferguson, Boll \& Holzer, 1967; Ferguson \& Sims, I97I; Katsunuma, Schött, Elsässer \& Holzer, I972; Lewis \& Fincham, 1970; Subramanian \& Sorger, 1972; Schimke \& Doyle, I970).

A basal NAD-GDH specific activity was found under all growth conditions. This activity increased approximately five- to eightfold during growth on glutamate as the sole carbon and nitrogen source. A smaller increase (three- to fourfold) in activity occurred in medium lacking a carbon source with ammonium present. Only a very slight increase occurred in medium lacking both carbon and nitrogen sources and no increase in NAD-GDH occurred in the presence of glucose. Surprisingly it was found that cycloheximide and acriflavin did not inhibit the increase in NAD-GDH specific activity as a result of the absence of glucose (Fig. I, Table I). In fact, acriflavin may have caused some increase in activity. Acriflavin and cycloheximide were certainly effective under these conditions because they simultaneously inhibited the loss of NADP-GDH activity. These results suggest that protein synthesis is not required for the increase in NAD-GDH activity. There is an apparent anomalous result in the lack of effect of the inhibitors on the increase in NAD-GDH activity in medium in which glutamate is the sole carbon and nitrogen source. It might have 


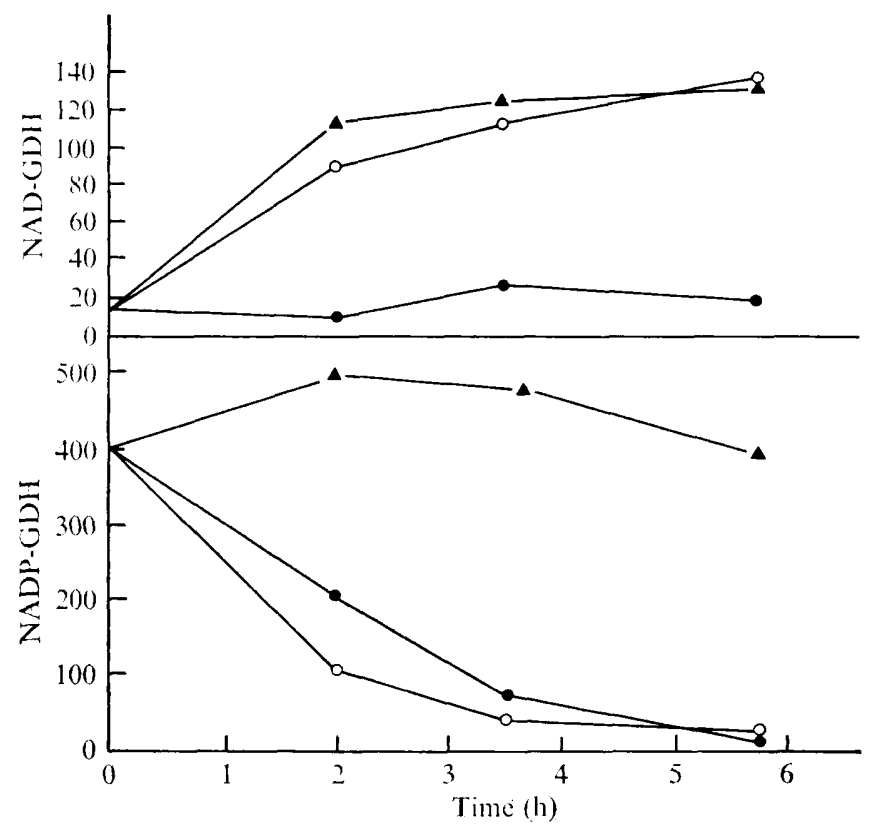

Fig. I. NAD-GDH and NADP-GDH specific activities of the wild-type strain. Wild-type mycelium was grown for $18 \mathrm{~h}$ in glucose- $0.5 \times 10^{-2} \mathrm{M}$-urea medium and then transferred to various media. Samples for enzyme assay were taken at intervals. 0 , No carbon or nitrogen source; $0,10^{-2}$ M-glutamate; $\boldsymbol{\Delta}, \quad{ }^{-2} \mathrm{M}$-glutamate +cycloheximide $(\mathrm{I} 0 \mu \mathrm{g} / \mathrm{ml})$ - all added to minimal salts solution. NAD-GDH specific activity expressed as nmol reduced NAD oxidized $/ \mathrm{min}_{i} \mathrm{mg}$ protein. NADP-GDH specific activity expressed as nmol $\mathrm{NADP}^{+}$reduced $/ \mathrm{min} / \mathrm{mg}$ protein.

Table I. Glutamate dehydrogenase activities of wild-type strain (amd $\left.T^{+}\right)$

Growth conditions*

Glucose $+10^{-2} \mathrm{M}-\mathrm{NH}_{4}+$

No carbon source $+10^{-2} \mathrm{M}-\mathrm{NH}_{4}+$

No carbon source $+10^{-2} \mathrm{M}-\mathrm{NH}_{4}{ }^{+}+$cycloheximide $(\mathrm{I} 5 \mu \mathrm{g} / \mathrm{ml})$

No carbon source $+\mathrm{IO}^{-2} \mathrm{M}-\mathrm{NH}_{4}++$ acriflavin $(15 \mu \mathrm{g} / \mathrm{ml})$

Glucose $+10^{-2} \mathrm{M}$-glutamate

Glucose $+10^{-2} \mathrm{M}$-glutamate + cycloheximide $(15 \mu \mathrm{g} / \mathrm{ml})$

Glucose $+10^{-2} \mathrm{M}$-glutamate + acriflavin $(15 / \mathrm{g} / \mathrm{ml})$

$10^{-2} \mathrm{M}$-glutamate

$10^{-2} \mathrm{M}$-glutamate + cycloheximide $(15 \mu \mathrm{g} \mathrm{ml})$

$10^{-2} \mathrm{M}$-glutamate + acriflavin $(\mathrm{I} 5 \mu \mathrm{g} ; \mathrm{ml})$

Glucose + no nitrogen source

No carbon or nitrogen source

No carbon or nitrogen source + cycloheximide $(\mathrm{I} 5 \mu \mathrm{g} / \mathrm{ml})$

No carbon or nitrogen source + acriflavin $(15 \mu \mathrm{g} / \mathrm{ml})$
Specific activities

$\begin{array}{cc}\text { NAD-GDH } \uparrow & \text { NADP-GDH }+ \\ 26 & 3 \text { I I } \\ 92 & 78 \\ 65 & 267 \\ 93 & 154 \\ 26 & 250 \\ 24 & 307 \\ 76 & 312 \\ 217 & 28 \\ 131 & 406 \\ 171 & 447 \\ 23 & 343 \\ 47 & 42 \\ 46 & 455 \\ 77 & 398\end{array}$

${ }^{*}$ Mycelium was grown for $\mathrm{I} 6 \mathrm{~h}$ on glucose- $10^{-2} \mathrm{M}^{-\mathrm{NH}_{4}}{ }^{+}$medium and then transferred to this medium for $4 \mathrm{~h}$.

+ Expressed as nmol of reduced NAD oxidized $/ \mathrm{min} / \mathrm{mg}$ protein.

$\ddagger$ Expressed as nmol of $\mathrm{NADP}^{+}$reduced $/ \mathrm{min} / \mathrm{mg}$ protein.

been expected that glutamate uptake capacity would not develop under these conditions, and NAD-GDH activity would be similar to that on medium lacking both carbon and nitrogen sources. A tentative explanation of this result is that the inhibitors, by blocking protein synthesis, lead to intracellular accumulation of amino acids, including glutamate. 


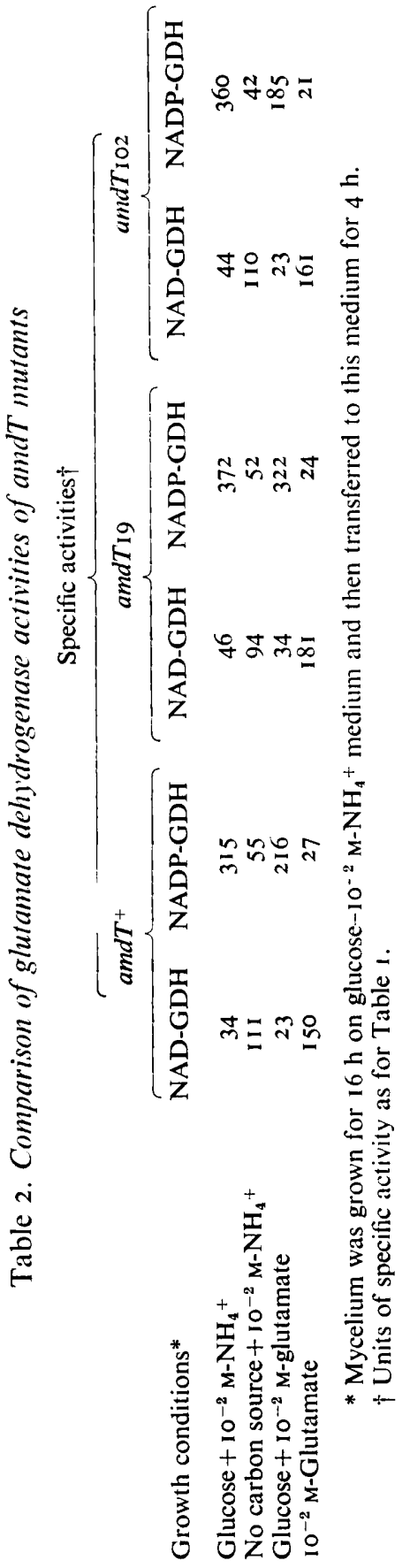


The glutamate dehydrogenase activities of $a m d T^{+}, a m d T_{19}$ and $a m d T_{\mathrm{I} 02}$ strains are compared in Table 2. There were no apparent differences between the strains in NAD-GDH activities. Similarly, the NADP-GDH activities of the amdT mutants were similar to wild type. The only evident difference occurred in strains grown on glucose-10 ${ }^{-2} \mathrm{M}$-glutamate. NADP-GDH activity of the $a m d T_{I} 9$ strain was higher than that of the $a m d T^{+}$and $a m d T_{102}$ strains in this medium. This can be explained by greatly reduced glutamate uptake capacity in the presence of glucose in andTI9 (Hynes, I973 $b$ ) and the consequent inability to grow on glutamate in the presence of glucose. Therefore little repression of NADP-GDH by glutamate and dilution of enzyme by growth was possible in the amdT I 9 mutant.

\section{DISCUSSION}

The isolation of mutants of Aspergillus nidulans lacking each of the glutamate dehydrogenases has provided clear evidence for the NADP-GDH being responsible for amination of 2-oxoglutarate (i.e. a biosynthetic role), and NAD-GDH being responsible for the deamination of glutamate (i.e. a catabolic role) (Kinghorn \& Pateman, 1973; Arst \& MacDonald, 1973). Compatible with these functions are the repression of NADP-GDH by glutamate and the increased activity of NAD-GDH in medium containing glutamate as the sole carbon source.

In mutants deficient in NADP-GDH activity in both yeast and Aspergillus nidulans a number of enzymes and uptake systems have been found to have reduced sensitivity to the effects of ammonium (Dubois, Grenson \& Wiame, I973; Arst \& MacDonald, I973; Pateman, Kinghorn, Dunn \& Forbes, 1973). It has therefore been suggested that NADP-GDH is necessary for ammonium repression of these enzymes and uptake systems. Starving $A$. nidulans for a carbon source leads to relief of ammonium repression of the acetamidase enzyme (Hynes, 1970) and glutamate uptake (Hynes, 1973 b). The utilization of acetamide and glutamate as sole carbon sources is not inhibited by ammonium. The rapid loss of NADP-GDH activity upon transfer to medium lacking glucose provides an important factor in proposing explanations of these results. When glucose is absent, NADP-GDH is rapidly lost (degraded) and this leads to relief of the effects of ammonium. However, Arst \& Cove (I973) have evidence, supported by results from this laboratory, for additional regulatory mechanisms which are active when glucose is absent.

The amdTI9 and amdT102 mutants seem to be normal in their regulation of glutamate dehydrogenase activities. Therefore the pleiotropic effects of these amdT lesions on nitrogen source utilization do not appear to result from alterations in amination or deamination of 2-oxoglutarate. This is particularly significant in view of the recent finding that the andT locus is involved in ammonium repression (Arst \& Cove, 1973). Recent results indicate that glutamine synthetase activities are not significantly altered in the amdT mutants.

The technical help of Iole Barbieri is greatly appreciated. This work was supported by the Australian Research Grants Committee.

\section{REFERENCES}

ARST, H. N. \& Cove, D. J. (1973). Nitrogen metabolite repression in Aspergillus nidulans. Molecular and General Genetics (in the Press).

ARst, H. N. \& MACDonald, D. W. (1973). A mutant of Aspergillus nidulans lacking NADP-linked glutamate dehydrogenase. Molecular and General Genetics 122, 26I-266. 
Dubois, E., Grenson, M. \& Wiame, J. M. (I973). Release of the 'ammonia effect' on three catabolic enzymes of NADP-specific glutamate dehydrogenaseless mutations in Saccharomyces cerevisiae. Biochemical and Biophysical Research Communications 50, 967-972.

Ferguson, J. J., Boll, M. \& Holzer, H. (I967). Yeast malate dehydrogenase: enzyme inactivation in catabolite repression. European Journal of Biochemistry I, $2 \mathrm{I}-25$.

Ferguson, A. R. \& Sims, A. P. (I97I). Inactivation in vivo of glutamine synthetase and NAD-specific glutamate dehydrogenase: its role in the regulation of glutamine synthesis in yeasts. Journal of General Microbiology 69, 423-427.

Hynes, M. J. (1970). Induction and repression of amidase enzymes in Aspergillus nidulans. Journal of Bacteriology 103, 482-487.

HyNES, M. J. (1972). Mutants with altered glucose repression of amidase enzymes in Aspergillus nidulans. Journal of Bacteriology III, 717-722.

Hynes, M. J. (1973a). Pleiotropic mutants affecting control of nitrogen metabolism in Aspergillus nidulans. Molecular and General Genetics 125, 99-107.

HYNES, M. J. (1973b). Alterations in the control of glutamate uptake in mutants of Aspergillus nidulans. Biochemical and Biophysical Research Communications 54, 685-689.

HYNES, M. J. (I973c). The effect of lack of a carbon source on nitrate-reductase activity in Aspergillus nidulans. Journal of General Microbiology 79, I 55-I 57.

KapoOR, M. \& Grover, A. K. (I970). Catabolite-controlled regulation of glutamate dehydrogenases of Neurospora crassa. Canadian Journal of Microbiology 16, 33-40.

Katsunuma, T., Schött, E., Elsässer, S. \& Holzer, H. (1972). Purification and properties of tryptophansynthase-inactivating enzymes from yeast. European Journal of Biochemistry 27, 520-526.

Kinghorn, J. R. \& Pateman, J. A. (1973). The regulation of nicotinamide-adenine-dinucleotide glutamate dehydrogenase in Aspergillus nidulans. Biochemical Society Transactions I, 675-676.

LewIS, C. M. \& FINChAM, J. R. S. (1970). Regulation of nitrate reductase in the basidiomycete Ustilago maydis. Journal of Bacteriology ro3, 55-6I.

Pateman, J. A. (1969). Regulation of synthesis of glutamate dehydrogenase and glutamine synthetase in microorganisms. Biochemical Journal $\mathbf{1 5}, 769-775$.

Pateman, J. A., Kinghorn, J. R., Dunn, E. \& Forbes, E. (1973). Ammonium regulation in Aspergillus nidulans. Journal of Bacteriology II4, 943-950.

Schimke, R. T. \& Doyle, D. (1970). Control of enzyme levels in animal tissues. Annual Review of Biochemistry 39, 929-976.

Subramanian, K. N. \& Sorger, G. J. (1972). Regulation of nitrate reductase in Neurospora crassa: stability in vivo. Journal of Bacteriology $\mathbf{1 0}, 538-546$. 